\title{
Enzyme immunoassay for mouse epidermal growth factor in a liquid phase double-antibody system
}

\author{
Masanori Kashimata, Masahiko Hiramatsu, Masayoshi Kumegawa*, \\ Naoyuki Minami and Naomi Minami \\ Departments of Dental Pharmacology and *Oral Anatomy, Josai Dental University, \\ Sakado, Saitama 350-02, Japan
}

[Accepted for publication: September 18, 1985]

Key words: Enzyme immunoassay / epidermal growth factor/mouse submandibular gland

Epidermal growth factor (EGF), a single chain polypeptide of 53 amino acids, was first isolated from male mouse submandibular glands ${ }^{11}$ and subsequently from human urine $^{2)}$. This peptide is a potent mitogen and differentiating factor for a variety of cells in vivo and in vitro, and its biological functions have been studied extensively ${ }^{3-5}$. For example, it accelerates incisor eruption and eyelid opening when given in newborn animals, and inhibits gastric acid secretion and promotes the healing of corneal epithelium of adult animals. It acts as a trophic factor for gastrointestinal mucosa ${ }^{6}$.

EGF is present in extremely high concentrations in the mouse submandibular gland, and its synthesis in the gland is under the control of endogenous androgens ${ }^{7)}$. Low levels of EGF are detectable in various tissues and fluids of both mice and humans, and are based on determinations made by radioimmunoassay $^{8-10)}$ or radioreceptor assay ${ }^{11}$. In this study, we developed an enzyme immunoassay for mouse EGF in a liquid phase double-antibody system.

\section{Materials and Methods}

Materials. EGF was isolated from the submandibular glands of adult male mice of the ICR strain by the method of Savage and Cohen ${ }^{12)}$. The isolated preparation gave a single protein band on polyacrylamide-gel electrophoresis ${ }^{13)}$. Anti-EGF rabbit serum was purchased from Collaborative Research, Waltham, MA. Goat anti-rabbit immunoglobulin $\mathrm{G}$ (IgG) was obtained from Cappel
Laboratories, Malvern, PA, and $\beta$-galactosidase (EC 3.2.1.23, from Escherichia coli) from Boehringer Mannheim, Mannheim, West Germany. N-Hydroxysuccinimide ester of $\mathrm{N}$-(4-carboxycyclohexylmethyl) -maleimide (CHM) was purchased from Zieben Chemical Co., Tokyo.

Preparation of EGF- $\beta$-galactosidase conjugate. The procedures are essentially based on the method reported by Yamamoto et $a l .{ }^{14)}$ for the preparation of thyroid hormone$\beta$-galactosidase conjugates. EGF $(0.5 \mathrm{mg})$ was dissolved in $0.5 \mathrm{ml}$ of $0.1 \mathrm{M}$ phosphate buffer, $\mathrm{pH} \mathrm{7.0,} \mathrm{and} \mathrm{the} \mathrm{solution} \mathrm{mixed} \mathrm{with}$ $20 \mu \mathrm{l}$ of N-hydroxysuccinimide ester of CHM ( $30 \mathrm{mg} / \mathrm{ml}$, dissolved in dimethylformamide). The mixture was incubated for $90 \mathrm{~min}$ at $30^{\circ} \mathrm{C}$, and then passed through a column $(1 \times 26 \mathrm{~cm})$ of Sephadex G-25 equilibrated with $0.1 \mathrm{M}$ phosphate buffer, $\mathrm{pH} 7.0$, containing $1 \mathrm{mM}$ EDTA. The fractions containing proteins were combined and mixed with $60 \mu \mathrm{l}$ of $\beta$-galactosidase $(5 \mathrm{mg} / \mathrm{ml}$, dissolved in the above buffer). The mixture was incubated for $30 \mathrm{~min}$ at $30^{\circ} \mathrm{C}$. After incubation, $30 \mu \mathrm{l}$ of $0.1 \mathrm{M} \beta$-mercaptoethylamine was added, and the mixture was further incubated for $10 \mathrm{~min}$ at room temperature.

The mixture was then applied to a column $(1.6 \times 45 \mathrm{~cm})$ of Sephacryl S-300 equilibrated with $0.1 \mathrm{M}$ phosphate buffer, $\mathrm{pH} 7.0$, and eluted with the same buffer. The major fractions containing $\beta$-galactosidase were collected and combined. To the solution, bovine serum albumin, $\mathrm{MgCl}_{2}$ and $\mathrm{NaN}_{3}$ were added as stabilizers to give a final concentration of $0.1,0.01$ and $0.1 \%$, respectively. 
The conjugate solution prepared was stored at $4^{\circ} \mathrm{C}$, and it was stable for at least 6 months.

Enzyme immunoassay. One hundred $\mu \mathrm{l}$ of tissue extract or standard solution containing various amounts of EGF was mixed with $100 \mu \mathrm{l}$ of anti-EGF serum previously diluted to $1: 500,000$ with $0.05 \mathrm{M}$ phosphate buffer, $\mathrm{pH} 7.3$, containing $0.1 \mathrm{M} \mathrm{NaCl}, 0.1 \%$ bovine serum albumin, $0.1 \%$ EDTA and $0.1 \%$ $\mathrm{NaN}_{3}$ (buffer A). After incubation for $1 \mathrm{~h}$ at $4^{\circ} \mathrm{C}, 100 \mu \mathrm{l}$ of EGF- $\beta$-galactosidase conjugate previously diluted to $1: 10,000$ with buffer $\mathrm{A}$ was added. The mixture was incubated for $24 \mathrm{~h}$ at $4^{\circ} \mathrm{C}$. Then, $50 \mu \mathrm{l}$ each of 10 -fold diluted goat anti-rabbit IgG serum and 100-fold diluted normal rabbit serum was added. These sera were diluted with buffer $\mathrm{A}$. The mixture was further incubated for $24 \mathrm{~h}$ at $4^{\circ} \mathrm{C}$.

The precipitate was collected by centrifugation at $3,000 \times g$ for $10 \mathrm{~min}$ and washed twice with $1 \mathrm{ml}$ of $0.02 \mathrm{M}$ phosphate buffer, $\mathrm{pH} 7.0$, containing $0.1 \mathrm{M} \mathrm{NaCl}, 0.1 \%$ bovine serum albumin, $0.01 \% \quad \mathrm{MgCl}_{2}$ and $0.1 \%$ $\mathrm{NaN}_{3}$ (buffer B). One fifth $\mathrm{ml}$ of $0.02 \mathrm{M}$ 0 -nitrophenyl- $\beta$-galactopyranoside dissolved in buffer $\mathrm{B}$ containing $0.35 \%$ 2-mercaptoethanol was added to the precipitate, and the suspension incubated for $18 \mathrm{~h}$ at $37^{\circ} \mathrm{C}$. After incubation, the enzyme reaction was stopped by adding $1 \mathrm{ml}$ of $0.1 \mathrm{M}$ glycine$\mathrm{NaOH}$ buffer, $\mathrm{pH} 10.3$, and the absorbance of the product, 0-nitrophenol was measured at $420 \mathrm{~nm}$ in a $1-\mathrm{ml}$ microcuvette.

\section{Results and Discussion}

Fig. 1 shows a typical standard curve of enzyme immunoassay for EGF. The binding of EGF- $\beta$-galactosidase conjugate to antiEGF antibody was dose-dependently decreased by the addition of increasing quantities of free EGF in the range from 10 to $1000 \mathrm{pg}$ per tube. About $100 \mathrm{pg}$ of EGF showed a 50 percent inhibition of binding. Several analysis showed no apparent alteration in the pattern of the standard curve. In addition, the slope of dilution curves generated by extracts of male and female submandibular glands was almost

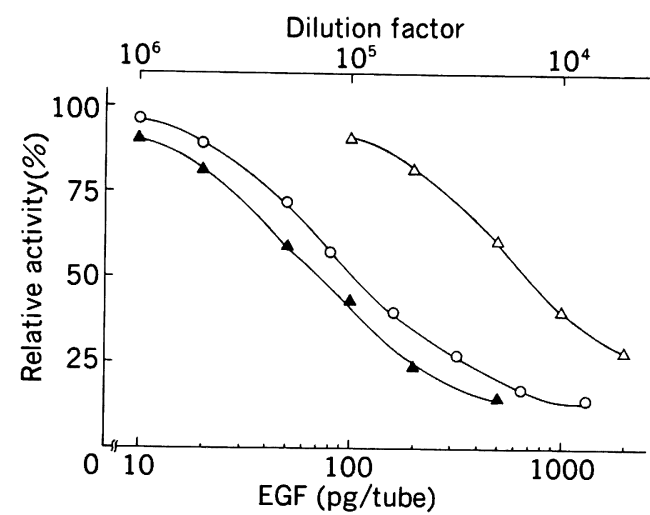

Fig. 1 Standard curve for EGF (O), and dilution curves generated by male $(\Delta)$ and female $(\Delta)$ extracts of submandibular glands. The glands were removed from 10-week-old ICR mice and homogenized with 9 volumes of saline. The homogenate was centrifuged at $10,000 \times g$ for $30 \mathrm{~min}$. The supernatant obtained was serially diluted by saline and assayed for EGF concentrations.

parallel to that of the standard curve. The concentration of EGF in the mouse submandibular gland was about 10 -fold higher in males than in females as reported previous$\mathrm{ly}^{8)}$. Several other peptides in the mouse submandibular gland, $\beta$-nerve growth factor, EGF-binding protein and esteroprotease $A^{15)}$, had no competitive binding to the EGF antibody.

The enzyme immunoassay for EGF in a liquid phase double-antibody system presented here is sufficiently sensitive, since this method can detect as low as $20 \mathrm{pg}$ EGF per tube, and thus the sensitivity seems to be higher than that of radioimmunoassay ${ }^{8-10}$. The EGF- $\beta$-galactosidase conjugate prepared in this study contains less than 20 percent of free $\beta$-galactosidase, which can be easily removed by washing the precipitate of antigen-antibody complex. Moreover, the conjugate is stable for at least 6 months. There is no need for use of radioisotopes throughout the procedures.

In the present assay, we measured $\beta$ galactosidase activity with the use of 0 -nitro- 
phenyl- $\beta$-galactopyranoside as a substrate. If the enzyme activity is measured fluorophotometrically with the use of another substrate, 4-methylumbelliferyl- $\beta$-galactopyranoside, under the condition of a further dilution of both the conjugate and antibody, a higher sensitivity could be expected.

\section{References}

1) Cohen, S.: Isolation of a mouse submaxillary gland protein accelerating incisor eruption and eyelid opening in the new-born animal. J. Biol. Chem. 237: 1555-1562, 1962.

2) Gregory, H.: Isolation and structure of urogastrone and its relationship to epidermal growth factor. Nature 257: 325-327, 1975.

3) Cohen, S. and Taylor, J. M.: Epidermal growth factor: chemical and biological characterization. Recent Prog. Horm. Res. 30: 533-550, 1974.

4) Carpenter, G. and Cohen, S.: Epidermal growth factor. Annu. Rev. Biochem. 48: 193216, 1979.

5) Gospodarowicz, D.: Growth factors and their action in vivo and in vitro. J. Pathol. 141 : 201-233, 1983.

6) Hiramatsu, M., Kashimata, M., Minami, N., Minami, N. and Kumegawa, M.: Effect of epidermal growth factor on glucosamine-6phosphate synthetase activity in the colon of neonatal mice. J. Endocrinol. 105: 197-200, 1985.

7) Byyny, R. L., Orth, D. N. and Cohen, S.: Epidermal growth factor: effects of androgens and adrenergic agents. Endocrinology 95: 776-782, 1974.
8) Byyny, R. L., Orth, D. N. and Cohen, S.: Radioimmunoassay of epidermal growth factor. Endocrinology 90: 1261-1266, 1972.

9) Starkey, R. H. and Orth, D. N.: Radioimmunoassay of human epidermal growth factor (urogastrone). J. Clin. Endocrinol. Metab. 45: 1144-1153, 1977.

10) Perheentupa, J., Lakshmanan, J., Hoath, S. B., Beri, U., Kim, H., Macaso, T. and Fisher, D. A.: Epidermal growth factor measurement in mouse plasma: method, ontogeny, and sex difference. Am. J. Physiol. 248: E391-E396, 1985.

11) Hirata, Y. and Orth, D. N.: Epidermal growth factor (urogastrone) in human fluids: size heterogeneity. J. Clin. Endocrinol. Metab. 48: 673-679, 1979.

12) Savage, C. R. and Cohen, S.: Epidermal growth factor and a new derivative. Rapid isolation procedures and biological and chemical characterization. J. Biol. Chem. 247: 7609-7611, 1972.

13) Server, A. C. and Shooter, E. M.: Comparison of the arginine esteropeptidase associated with nerve and epidermal growth factors. J. Biol. Chem. 251: 165-173, 1976.

14) Yamamoto, R., Hattori, S., Inukai, T., Matsuura, A., Yamashita, K., Kosaka, A. and Kato, K.: Enzyme immunoassay for thyroxine and triiodothyronine in human serum, with use of a covalent chromatographic separation method. Clin. Chem. 27: 1721-1723, 1981.

15) Schenkein, I., Levy, M., Franklin, E. C. and Frangione, B.: Proteolytic enzymes from the mouse submaxillary gland. Specificity restricted to arginine residues. Arch. Biochem. Biophys. 182: 64-70, 1977. 